УДК 633.65

(C) 2013

Шевніков М. Я., доктор сільськогосподарських наук,

Логвиненко О. М., аспірант *

Полтавська державна аграрна академія

\title{
ВПЛИВ СТРОКІВ, СПОСОБІВ СІВБИ, НОРМ ВИСІВУ РІЗНИХ СОРТІВ СОЇ НА ЇЇ ПРОДУКТИВНІСТЬ
}

\section{Рецензент - доктор сільськогосподарських наук, професор С. М. Каленська}

\begin{abstract}
Запропоновані основні елементи сортової технології вирошування сої в умовах лівобережної частини Лісостепу України, зокрема строки, способи сівби та норми висіву. Норма висіву більше ніж спосіб сівби впливала на величину врожайності сої. Підвищення норми висіву до 800 тис./га схожих насінин, особливо за сівби в пізні строки, не сприяло суттевому підвищенню врожаю. Найбільш доиільно сою сіяти звичайним рядковим (15 cм) або широкорядним (45 cм) способами з нормою висіву 700 тис./га схожих насінин.
\end{abstract}

Ключові слова: соя, строки сівби, способи сівби, норми висіву, сорти, урожайність.

Постановка проблеми. У зв'язку з поширенням нових сортів сої постає питання 3'ясування елементів технології вирощування, які б забезпечили високу іï продуктивність. Особливе значення мають строки, способи сівби та норма висіву насіння сої. Соя, як світлолюбна культура, формує високий урожай лише за оптимальних для конкретного сорту площі живлення й густоти рослин, забезпечення вологою та поживними речовинами, а також при відповідній структурі посіву. Однак основна вимога - якнайкраще освітлення листкової поверхні. 3 впровадженням у виробництво адаптованих ранньостиглих сортів сої виникла проблема забезпечення гарантованого щорічного формування якісного врожаю насіння до настання несприятливих для збирання умов осіннього періоду. Подальше поширення сої в умовах нестійкого зволоження лівобережної частини Лісостепу стримується недостатньо обгрунтованою зональною технологією іiі вирощування, передусім за ранньої сівби, де тепло $є$ обмежуючим фактором. Потребують вивчення й процеси формування врожаю та якості насіння сої за різних строків сівби.

Спосіб сівби і густота розміщення рослин на площі залежить, в першу чергу, від особливостей сорту і метеорологічних умов, а також від взаємодії цих факторів. В останні роки спостері- гається тенденція до звуження міжрядь і збільшення густоти рослин. Тому питання правильного вибору способу сівби та норми висіву слід вирішувати стосовно вибраного сорту й місцевості. У зв'язку з цим особливого значення набуває раціональне використання ресурсів тепла у ранньовесняний період за рахунок ранніх строків сівби. Ці міркування і $є$ підставою для вивчення способів сівби і норм висіву сої в умовах нестійкого зволоження лівобережної частини Лісостепу України.

Аналіз основних досліджень i публікацій, у яких започатковано розв'язання проблеми. Для сої строк сівби має вирішальне значення, поскільки від нього залежить дружність сходів, густота рослин, рівномірність достигання, величина й якість врожаю. Основний критерій вибору строку посіву - стійке прогрівання посівного шару грунту. Мінімальна температура для сходів сої становить близько $+10{ }^{\circ} \mathrm{C}$ за тенденції до підвищення температури грунту. Прогрівання посівного шару до $+12-14{ }^{\circ} \mathrm{C}$ забезпечує дружнє проростання насіння за наявності вологи в ньому. У разі сівби насіння у більш ранній період йому потрібно більше часу для проростання, що збільшує різке ураження рослин хворобами i шкідниками, знижує схожість насіння [1].

Вибираючи строки сівби, слід розраховувати на повне використання рослинами вегетаційного періоду, родючості грунту, особливостей волого забезпечення місцевості, тому що критичний період за водоспоживанням повинен припадати на фазу цвітіння-формування бобів. Дослідження, проведені в Лісостепу України, вказують, що найбільшу урожайність одержано за сівби в роки з ранньою весною наприкінці квітня, в роки 3 пізньою весною - у першій декаді травня $[3,5]$.

Раціональне розміщення рослин на площі для створення оптимальних умов процесу фотосинтезу та функціонування кореневої системи $\epsilon$ предметом постійної уваги дослідників.

* Науковий керівник - доктор сільськогосподарських наук М. Я. Шевніков 
Відмічається, що для сої характерна властивість змінювати свою продуктивність відповідно 3 площею живлення. Так, у дослідах Кіровоградського інституту АПВ УААН не спостерігалося суттєвих коливань в урожайності насіння сої за збільшення ширини міжрядь від 15 до 60 см [4]. Вибираючи спосіб сівби, важливо враховувати високу пластичність сої до площі живлення, що проявляється в зміні індивідуальної продуктивності рослин. У посівах сої з оптимальною густотою й площею живлення рослин основна кількість бобів формується на головному пагоні, у зріджених - на бокових гілках. Негативна дія надмірного загущення призводить до вилягання, передчасного пожовтіння й опадання листків, неповного використання світла, вологи, поживних речовин, зниження біологічної фіксації азоту з атмосфери [2].

Збільшення норми висіву з 400 до 1200 тис./га рослин призводило до скорочення вегетаційного періоду, значного видовження рослин і зменшення врожайності насіння за рахунок утворення бобів лише у верхній частині рослин. У загущених посівах сої боби формувалися в центральній і верхній частинах стебла. Такі рослини швидко скидали листки, спостерігалося інтенсивне полягання й збільшувалися втрати за комбайнового збирання [6].

Отже, ширина міжрядь залежить від скоростиглості сорту, наявності посівної та збиральної техніки, родючості грунту, вологозабезпечення, здатності рослин до гілкування, характеру розміщення листків, форми й висоти рослин. Пізньостиглі сорти, схильні до вилягання і гілкування, краще ростуть за меншої густоти рослин, а ранньостиглі - більш стійкі до вилягання і ті, що не гілкуються, - за більшої густоти рослин.

Мета i методика проведення досліджень. Метою досліджень було встановлення оптимальної густоти посіву сої шляхом правильного вибору норми висіву і способу сівби, які б забезпечили оптимальний ріст і розвиток рослин та високу продуктивність. Визначаючи строки сівби, враховували, що ранній строк відповідає мінімальній температурі грунту $\left(8-10^{\circ} \mathrm{C}\right)$, за якої можливе проростання насіння сої. Оптимальний строк сівби визначали за умов прогрівання грунту до $+12-14{ }^{\circ} \mathrm{C}$. Пізній строк сівби відповідав підвищенню температури грунту до $+16-18{ }^{\circ} \mathrm{C}$. У перших двох випадках обов'язково враховували також достатнє вологозабезпечення верхнього шару грунту. Пізній строк сівби частіше супроводжувався низькою вологістю посівного шару грунту.

Польові дослідження проводили на дослідному полі навчально-дослідного господарства «Ювілейний» Полтавської державної аграрної академії. Грунт дослідної ділянки - чорнозем опідзолений середньосуглинковий із вмістом гумусу $3,7 \%, \mathrm{pH}_{\text {(сольвве) }}-5,6$. Метеорологічні умови в роки проведення дослідів були різноманітними й сповна характеризували особливості клімату даної місцевості.

Результати досліджень. У вирощуванні сої неабияке значення мають не тільки показники продуктивності, але й інші характеристики: висота рослин і галуження, висота прикріплення нижніх бобів, схильність до вилягання, тривалість вегетаційного періоду. В процесі росту i розвитку рослин спостерігалася постійна зміна поширення їх підземних і наземних органів у горизонтальному й вертикальному напрямах, змінюючи об'єми простору і грунту залежно від величини та конфігурації площі живлення.

Важливими показниками, що впливають на величину врожаю, є висота рослин і висота прикріплення нижніх бобів. Висота рослин змінювалася під впливом способу сівби. За суцільної рядкової сівби найнижчими рослини були за висіву 500 тис./га схожих насінин $(57,3-63,4$ см). Збільшення норми висіву сприяло збільшенню висоти рослин до $61,4-64,3 \mathrm{~cm}$ за висіву 600 тис./га, 60,7-64,6 см - за норми висіву 700 тис./га, 60,4-66,4 см - за висіву 800 тис./га схожих насінин залежно від сорту, строку та способу сівби (табл. 1).

Густота рослин безпосередньо впливала не тільки на висоту рослин, але й на висоту прикріплення нижніх бобів, що в значній мірі визначає втрати врожаю при механізованому збиранні. Зміна норми висіву від 500 до 800 тис./га схожих насінин за суцільної рядкової сівби сприяла збільшенню висоти прикріплення нижніх бобів від 11,7 см до 15,7 см, при широкорядній сівбі 3 міжряддями 45 см - від 12,0 см до 14,8 см за сівби в третій декаді квітня, відповідно, 12,2-15,7 та 11,4-15,3 - за сівби в першій декаді травня; $12,1-15,2$ см та $12,6-15,5$ см - за сівби в другій декаді травня. Як правило, у зріджених посівах у нижньому ярусі рослин формується значна маса врожаю насіння, - під їх вагою гілки схиляються до землі, спричиняючи втрати у ході збирання врожаю. У загущених посівах менша кількість бокових пагонів, але стебло досить тонке, що сприяє значному поляганню рослин. 


\section{1. Висота рослин і висота прикріплення нижніх бобів сої залежно від строків, способів сівби та норми висіву насіння соӥ (середнє за 2008-2010 роки)}

\begin{tabular}{|c|c|c|c|c|c|c|c|}
\hline \multirow[b]{2}{*}{ Спосіб сівби } & \multirow[b]{2}{*}{$\begin{array}{l}\text { Норма } \\
\text { висіву, } \\
\text { тис./га }\end{array}$} & \multicolumn{2}{|c|}{ Сорт Алмаз } & \multicolumn{2}{|c|}{ Сорт Аметист } & \multicolumn{2}{|c|}{ Сорт Антрацит } \\
\hline & & $\begin{array}{c}\text { висота } \\
\text { рослин, см }\end{array}$ & $\begin{array}{c}\text { висота } \\
\text { прикріп- } \\
\text { лення } \\
\text { нижнього } \\
\text { боба, см }\end{array}$ & $\begin{array}{c}\text { висота } \\
\text { рослин, см }\end{array}$ & $\begin{array}{c}\text { висота } \\
\text { прикріп- } \\
\text { лення } \\
\text { нижнього } \\
\text { боба, см }\end{array}$ & $\begin{array}{c}\text { висота } \\
\text { рослин, см }\end{array}$ & $\begin{array}{c}\text { висота } \\
\text { прикріп- } \\
\text { лення } \\
\text { нижнього } \\
\text { боба, см }\end{array}$ \\
\hline \multicolumn{8}{|c|}{ Строк сівби - третя декада квітня } \\
\hline \multirow{4}{*}{$\begin{array}{c}\text { Рядковий, } \\
15 \text { см }\end{array}$} & 500 & 57,3 & 11,7 & 53,3 & 11,9 & 60,4 & 13,9 \\
\hline & 600 & 61,4 & 12,9 & 56,5 & 12,8 & 62,1 & 14,5 \\
\hline & 700 & 62,6 & 14,1 & 57,1 & 13,6 & 60,7 & 15,4 \\
\hline & 800 & 64,4 & 14,8 & 60,4 & 14,2 & 62,5 & 15,7 \\
\hline \multirow{4}{*}{$\begin{array}{c}\text { Широко- } \\
\text { рядний, } \\
45 \mathrm{~cm}\end{array}$} & 500 & 58,1 & 12,0 & 58,2 & 12,5 & 61,3 & 14,3 \\
\hline & 600 & 63,7 & 12,4 & 57,9 & 13,3 & 62,6 & 13,8 \\
\hline & 700 & 62,9 & 13,8 & 59,5 & 14,0 & 63,0 & 14,4 \\
\hline & 800 & 63,8 & 14,3 & 60,3 & 14,8 & 63,5 & 14,1 \\
\hline \multicolumn{8}{|c|}{ Строк сівби - перша декада травня } \\
\hline \multirow{4}{*}{$\begin{array}{c}\text { Рядковий, } \\
15 \text { см }\end{array}$} & 500 & 59,2 & 12,8 & 58,0 & 12,2 & 62,9 & 14,2 \\
\hline & 600 & 61,4 & 13,6 & 59,6 & 13,4 & 64,3 & 14,8 \\
\hline & 700 & 65,5 & 14,5 & 61,2 & 14,1 & 64,8 & 14,6 \\
\hline & 800 & 62,9 & 14,4 & 63,7 & 14,7 & 64,5 & 15,7 \\
\hline \multirow{4}{*}{$\begin{array}{c}\text { Широко- } \\
\text { рядний, } \\
45 \mathrm{~cm}\end{array}$} & 500 & 61,8 & 11,4 & 58,9 & 12,8 & 63,4 & 13,8 \\
\hline & 600 & 59,6 & 13,5 & 64,2 & 13,5 & 63,3 & 14,1 \\
\hline & 700 & 64,3 & 12,6 & 62,9 & 13,8 & 64,1 & 14,5 \\
\hline & 800 & 63,1 & 14,8 & 64,3 & 13,6 & 64,7 & 15,3 \\
\hline \multicolumn{8}{|c|}{ Строк сівби - друга декада травня } \\
\hline \multirow{4}{*}{$\begin{array}{c}\text { Рядковий, } \\
15 \text { см }\end{array}$} & 500 & 61,0 & 12,7 & 56,8 & 12,1 & 61,8 & 14,3 \\
\hline & 600 & 63,2 & 13,6 & 59,4 & 13,0 & 62,5 & 14,9 \\
\hline & 700 & 64,6 & 14,3 & 62,7 & 13,6 & 63,6 & 14,8 \\
\hline & 800 & 66,4 & 15,2 & 60,5 & 14,3 & 64,3 & 15,2 \\
\hline \multirow{4}{*}{$\begin{array}{c}\text { Широко- } \\
\text { рядний, } \\
45 \text { см }\end{array}$} & 500 & 61,8 & 13,4 & 57,2 & 13,1 & 63,0 & 13,0 \\
\hline & 600 & 64,1 & 12,6 & 60,6 & 12,7 & 63,2 & 13,7 \\
\hline & 700 & 62,9 & 13,8 & 62,3 & 13,4 & 64,4 & 15,5 \\
\hline & 800 & 65,3 & 14,1 & 61,5 & 14,5 & 64,1 & 15,1 \\
\hline
\end{tabular}

Урожайність сої - це величина, що залежить від індивідуальної продуктивності однієї рослини та загальної їх кількості на гектарі. Потрібне таке співвідношення вищевказаних показників, яке б забезпечило отримання максимального врожаю з одиниці площі.

У наших дослідженнях кількість бобів і насінин на одній рослині найбільшою була за мінімальної норми висіву за всіх способів сівби (кількість бобів - 22,2-24,9; кількість насінин 45,9-47,5).

У загущених посівах даний показник був значно меншим. За збільшення густоти рослин до оптимальної продуктивність однієї рослини знижувалась, але загальна їі урожайність зростала за рахунок більшої кількості рослин на одиниці площі. Характерним було також зменшення гілок першого порядку, бобів і насіння на одній рослині. Подальше загущення сприяло видовженню і виляганню рослин, затіненню листків у нижньому та середньому ярусах, що негативно впливало на продуктивність рослин.

Коливання маси 1000 насінин визначається не лише особливостями сорту, але й способом сівби, нормою висіву та погодними умовами. У разі збільшення кількості рослин на площі маса 1000 насінин зменшувалася, при зменшенні - збільшувалась. Однак зміна у визначеному напрямі продуктивності однієї рослини при різній густоті рослин сої не сприяла зменшенню врожаю загущеного посіву. Аналізуючи співвідношення маси 1000 насінин та масу насінин $з$ однієї рослини, найбільш раціональною виявилася норма висіву 700 тис./га схожих насінин (табл. 2). 


\section{2. Вплив строку, способу сівби та норми висіву на показники структури врожаю сої} (середнс за 2008-2010 роки)

\begin{tabular}{|c|c|c|c|c|c|c|c|}
\hline \multirow[b]{2}{*}{$\begin{array}{l}\text { Спосіб } \\
\text { сівби }\end{array}$} & \multirow[b]{2}{*}{$\begin{array}{c}\text { Норма } \\
\text { висіву, } \\
\text { тис/га }\end{array}$} & \multicolumn{2}{|c|}{ Сорт Алмаз } & \multicolumn{2}{|c|}{ Сорт Аметист } & \multicolumn{2}{|c|}{ Сорт Антрацит } \\
\hline & & $\begin{array}{c}\text { маса насін- } \\
\text { ня з росли- } \\
\text { ни, г }\end{array}$ & $\begin{array}{l}\text { маса } 1000 \\
\text { насінин, Г }\end{array}$ & $\begin{array}{c}\text { маса насін- } \\
\text { ня з росли- } \\
\text { ни, г }\end{array}$ & $\begin{array}{l}\text { маса } 1000 \\
\text { насінин, Г }\end{array}$ & $\begin{array}{c}\text { маса насін- } \\
\text { ня з росли- } \\
\text { ни, г }\end{array}$ & $\begin{array}{l}\text { маса } 1000 \\
\text { насінин, г }\end{array}$ \\
\hline \multicolumn{8}{|c|}{ Строк сівби - третя декада квітня } \\
\hline \multirow{4}{*}{$\begin{array}{c}\text { Рядковий, } \\
15 \text { см }\end{array}$} & 500 & 5,9 & 134 & 5,2 & 121 & 5,1 & 133 \\
\hline & 600 & 5,5 & 129 & 5,4 & 137 & 4,9 & 122 \\
\hline & 700 & 5,3 & 139 & 4,8 & 119 & 4,6 & 120 \\
\hline & 800 & 4,1 & 113 & 4,5 & 124 & 4,8 & 135 \\
\hline \multirow{4}{*}{$\begin{array}{c}\text { Широко- } \\
\text { рядний, } \\
45 \text { см }\end{array}$} & 500 & 4,8 & 115 & 6,0 & 147 & 5,0 & 124 \\
\hline & 600 & 4,5 & 114 & 4,6 & 114 & 5,3 & 135 \\
\hline & 700 & 4,2 & 127 & 5,1 & 134 & 4,7 & 113 \\
\hline & 800 & 4,4 & 130 & 4,3 & 114 & 4,9 & 134 \\
\hline \multicolumn{8}{|c|}{ Строк сівби - перша декада травня } \\
\hline \multirow{4}{*}{$\begin{array}{c}\text { Рядковий, } \\
15 \text { см }\end{array}$} & 500 & 6,3 & 135 & 5,7 & 128 & 5,2 & 117 \\
\hline & 600 & 6,0 & 132 & 6,1 & 151 & 5,5 & 134 \\
\hline & 700 & 5,7 & 141 & 4,9 & 138 & 5,7 & 155 \\
\hline & 800 & 5,2 & 134 & 5,2 & 138 & 5,1 & 145 \\
\hline \multirow{4}{*}{$\begin{array}{c}\text { Широко- } \\
\text { рядний, } \\
45 \text { см }\end{array}$} & 500 & 6,6 & 147 & 5,4 & 110 & 6,1 & 154 \\
\hline & 600 & 6,2 & 146 & 5,8 & 143 & 5,4 & 131 \\
\hline & 700 & 5,1 & 142 & 4,0 & 102 & 5,0 & 133 \\
\hline & 800 & 4,4 & 121 & 4,6 & 127 & 5,2 & 150 \\
\hline \multicolumn{8}{|c|}{ Строк сівби - друга декада травня } \\
\hline \multirow{4}{*}{$\begin{array}{c}\text { Рядковий, } \\
15 \text { см }\end{array}$} & 500 & 6,4 & 143 & 5,5 & 131 & 5,6 & 132 \\
\hline & 600 & 5,6 & 143 & 5,1 & 121 & 5,3 & 130 \\
\hline & 700 & 5,3 & 142 & 4,7 & 113 & 5,2 & 141 \\
\hline & 800 & 5,0 & 142 & 4,2 & 116 & 4,7 & 137 \\
\hline \multirow{4}{*}{$\begin{array}{c}\text { Широко- } \\
\text { рядний, } \\
45 \text { см }\end{array}$} & 500 & 6,2 & 136 & 6,0 & 137 & 5,1 & 132 \\
\hline & 600 & 6,5 & 151 & 5,3 & 114 & 4,8 & 130 \\
\hline & 700 & 4,9 & 131 & 5,5 & 144 & 4,6 & 123 \\
\hline & 800 & 4,7 & 128 & 4,1 & 115 & 4,9 & 138 \\
\hline
\end{tabular}

Вибираючи спосіб сівби, слід враховувати високу пластичність сої до площі живлення, що проявляється в зміні індивідуальної продуктивності рослин. У посівах з оптимальною густотою і площею живлення рослин основна кількість бобів формується на головному пагоні, у зріджених - на бокових гілках. Негативна дія надмірного загущення призводить до вилягання, передчасного пожовтіння та опадання листків, неповного використання світла, вологи, поживних речовин, зниження біологічної фіксації азоту з атмосфери. Соя чутлива до зміни величини й форми площі живлення рослин у посіві. Максимальне використання продуктів фотосинтезу у неї припадає на репродуктивну стадію, тому ширина міжрядь і площа живлення рослин має бути такою, щоб рослинний покрив повністю застилав грунтову поверхню до початку цвітіння. У загущеному посіві боби формуються у верхній частині рослин, - наслідком цього є низька урожайність насіння. За зрідженого розміщення рослин характерне близьке до поверхні грунту закладання бобів, що призводить до значних втрат врожаю під час збирання.

Норма висіву більше, ніж спосіб сівби, впливала на величину врожайності сої (табл. 3). Найкращі умови склалися за висіву 700 тис./га схожих насінин. Підвищення норми висіву до 800 тис./га схожих насінин, передусім за сівби в пізні строки, не сприяло суттєвому підвищенню врожаю. Тому найдоцільніше сою сіяти звичайним рядковим (15 см) або широкорядним (45 см) способами 3 нормою висіву 700 тис./га схожих насінин.

\section{Висновки:}

1. Зміна густоти рослин сої впливала на ступінь використання основних життєвих факторів, a їх взаємодія визначала величину врожаю та його структуру. Висота рослин змінювалася під впливом способу сівби. За суцільної рядкової 
3. Урожайність насіння різних сортів сої залежно від строків, способів сівби та норми висіву (середнє за 2008-2010 роки)

\begin{tabular}{|c|c|c|c|c|c|c|c|}
\hline \multirow[b]{2}{*}{$\begin{array}{l}\text { Спосіб } \\
\text { сівби }\end{array}$} & \multirow[b]{2}{*}{$\begin{array}{l}\text { Норма } \\
\text { висіву, } \\
\text { тис./га }\end{array}$} & \multicolumn{2}{|c|}{ Сорт Алмаз } & \multicolumn{2}{|c|}{ Сорт Аметист } & \multicolumn{2}{|c|}{ Сорт Антрацит } \\
\hline & & $\begin{array}{c}\text { урожай- } \\
\text { ність насін- } \\
\text { ня, ц/га }\end{array}$ & \begin{tabular}{|c|} 
відхилення \\
врожайнос- \\
ті, \pm га
\end{tabular} & $\begin{array}{c}\text { урожай- } \\
\text { ність насін- } \\
\text { ня, ц/га }\end{array}$ & \begin{tabular}{|c} 
відхилення \\
врожайнос- \\
ті, \pm „ца
\end{tabular} & $\begin{array}{c}\text { урожай- } \\
\text { ність насін- } \\
\text { ня, ц/га }\end{array}$ & \begin{tabular}{|c} 
відхилення \\
врожайнос- \\
ті, \pm $/$ га
\end{tabular} \\
\hline \multicolumn{8}{|c|}{ Строк сівби - третя декада квітня } \\
\hline \multirow{4}{*}{$\begin{array}{c}\text { Рядковий, } \\
15 \mathrm{~cm}\end{array}$} & 500 & 19,5 & - & 16,1 & - & 17,3 & - \\
\hline & 600 & 22,0 & $+2,5$ & 21,6 & $+5,5$ & 18,1 & $+0,8$ \\
\hline & 700 & 23,3 & $+3,8$ & 21,6 & $+5,5$ & 22,5 & $+5,2$ \\
\hline & 800 & 23,8 & $+4,3$ & 23,4 & $+7,3$ & 21,6 & $+4,3$ \\
\hline \multirow{4}{*}{$\begin{array}{l}\text { Широко- } \\
\text { рядний, } \\
45 \text { см }\end{array}$} & 500 & 16,8 & - & 20,4 & - & 17,5 & - \\
\hline & 600 & 19,4 & $+2,6$ & 23,0 & $+2,6$ & 20,7 & $+3,2$ \\
\hline & 700 & 24,8 & $+8,0$ & 24,5 & $+4,1$ & 24,0 & $+6,5$ \\
\hline & 800 & 24,0 & $+7,2$ & 25,3 & $+4,9$ & 25,4 & $+7,9$ \\
\hline \multicolumn{8}{|c|}{ Строк сівби - перша декада травня } \\
\hline \multirow{4}{*}{$\begin{array}{c}\text { Рядковий, } \\
15 \text { см }\end{array}$} & 500 & 24,6 & - & 21,7 & - & 21,2 & - \\
\hline & 600 & 28,8 & $+4,2$ & 22,0 & $+0,3$ & 23,1 & $+1,9$ \\
\hline & 700 & 29,1 & $+4,5$ & 25,0 & $+3,3$ & 28,5 & $+7,3$ \\
\hline & 800 & 31,7 & $+7,1$ & 27,2 & $+5,5$ & 27,5 & $+6,3$ \\
\hline \multirow{4}{*}{$\begin{array}{l}\text { Широко- } \\
\text { рядний, } \\
45 \text { см }\end{array}$} & 500 & 23,8 & & 21,1 & 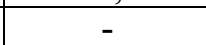 & 23,2 & - \\
\hline & 600 & 26,0 & $+2,2$ & 22,5 & $+1,4$ & 24,8 & $+1,6$ \\
\hline & 700 & 27,0 & $+3,2$ & 26,4 & $+5,3$ & 26,0 & $+2,8$ \\
\hline & 800 & 27,8 & $+4,0$ & 28,1 & $+7,0$ & 27,7 & $+4,5$ \\
\hline \multicolumn{8}{|c|}{ Строк сівби - друга декада травня } \\
\hline \multirow{4}{*}{$\begin{array}{c}\text { Рядковий, } \\
15 \text { см }\end{array}$} & 500 & 22,4 & - & 18,2 & - & 19,0 & - \\
\hline & 600 & 23,5 & $+1,1$ & 19,4 & $+1,3$ & 22,8 & $+3,8$ \\
\hline & 700 & 23,3 & $+0,9$ & 22,1 & $+3,9$ & 23,9 & $+4,9$ \\
\hline & 800 & 24,0 & $+1,6$ & 23,1 & $+4,9$ & 24,7 & $\begin{array}{r}+5,7 \\
\end{array}$ \\
\hline \multirow{4}{*}{$\begin{array}{l}\text { Широко- } \\
\text { рядний, } \\
45 \text { см }\end{array}$} & 500 & 20,5 & - & 21,6 & - & 18,9 & 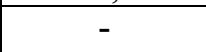 \\
\hline & 600 & 24,3 & $+3,8$ & 22,8 & $+1,2$ & 22,1 & $+3,2$ \\
\hline & 700 & 29,5 & $+9,0$ & 27,5 & $+5,9$ & 26,5 & $+7,6$ \\
\hline & 800 & 27,7 & $\begin{array}{r}+7,2 \\
\end{array}$ & 23,8 & $+2,2$ & 24,5 & $\begin{array}{r}+5,6 \\
\end{array}$ \\
\hline $\mathrm{HIP}_{05}$ & & 1,3 & & 0,9 & & 1,2 & \\
\hline
\end{tabular}

сівби найнижчими рослини були за висіву 500 тис./га схожих насінин (57,3-63,4 см). 3більшення норми висіву сприяло збільшенню висоти рослин до 61,4-64,3 см за висіву 600 тис./га, 60,7-64,6 см - за норми висіву 700 тис./га, 60,4-66,4 см - за висіву 800 тис./га схожих насінин залежно від сорту, строку та способу сівби.

2. Норма висіву більше, ніж спосіб сівби,

\section{БІБЛІОГРАФІЯ}

1. Бабич А. О. Світові земельні, продовольчі і кормові ресурси / Анатолій Олександрович Бабич. - К. : Аграрна наука, 1996. - 200 с.

2. Бабич $A$. О. Проблема фотосинтезу і біологічної фіксації азоту бобовими культурами / А. О. Бабич, В. Ф. Петриченко, Ф. Ф. Адамень // Вісник аграрної науки. - № 3. - 1996. - С. 34-39.

3. Грииун А. Основы возделывания сои в Приморье / Грицун А. - Владивосток : Дальневост. кн. изд-во, 1981. - 159 с. - (Монография). впливала на величину врожайності сої. Найкращі умови склалися за висіву 700 тис./га схожих насінин. Підвищення норми висіву до 800 тис./га схожих насінин, особливо за сівби в пізні строки, не сприяло суттєвому підвищенню врожаю. Тому найбільш доцільно сою сіяти звичайним рядковим (15 см) або широкорядним (45 см) способами 3 нормою висіву 700 тис./га схожих насінин.

4. Гроздинский А. М. Аллелопатия в жизни растений и их сообществ / Гроздинский А. М. - К. : Наукова думка, 1965. - 200 с. - (Монография).

5. Дерев'янський В. П. Кулісна технологія вирощування сої / В. П. Дерев'янський, Р. О. Городнюк. - К. : УкрIНTЕI, 1994. - 16 с.

6. Камінський В. Ф. Комплексний вплив факторів інтенсифікації на формування врожаю сої у північному Лісостепу / В. Ф. Камінський // Вісник аграрної науки. - 2006. - № 9. - С. 36-42. 